\title{
Toxicity and antitumor potential of Mesosphaerum sidifolium (Lamiaceae) oil and fenchone, its major component
}

Thaísa Leite Rolim, Déborah Ribeiro Pessoa Meireles', Tatianne Mota Batista', Tatyanna Kelvia Gomes de Sousa', Vivianne Mendes Mangueira', Renata Albuquerque de Abrantes ${ }^{1}$, João Carlos Lima Rodrigues Pita', Aline Lira Xavier', Vicente Carlos Oliveira Costa', Leônia Maria Batista ${ }^{1,2}$, Marcelo Sobral da Silva ${ }^{1,2}$ and Marianna Vieira Sobral ${ }^{1,2^{*}}$

\begin{abstract}
Background: The essential oil from Mesosphaerum sidifolium (L'Hérit.) Harley \& J.F.B.Pastore (syn. Hyptis umbrosa), Lamiaceae (EOM), and its major component, have been tested for toxicity and antitumor activity.

Methods: EOM was obtained from aerial parts of M. sidifolium subjected to hydro distillation, and gas chromatographymass spectrometry was used to characterize the EOM chemical composition. The toxicity was evaluated using haemolysis assay, and acute toxicity and micronucleus tests. Ehrlich ascites carcinoma model was used to evaluate the in vivo antitumor activity and toxicity of EOM (50, 100 and $150 \mathrm{mg} / \mathrm{kg}$ ), and fenchone (30 and $60 \mathrm{mg} / \mathrm{kg})$ after $9 \mathrm{~d}$ of treatment.

Results: The EOM major components were fenchone (24.8\%), cubebol (6.9\%), limonene (5.4\%), spathulenol (4.5\%), $\beta$-caryophyllene (4.6\%) and a-cadinol (4.7\%). The HC50 (concentration producing 50\% haemolysis) was $494.9 \mu \mathrm{g} / \mathrm{mL}$ for EOM and higher than $3000 \mu \mathrm{g} / \mathrm{mL}$ for fenchone. The LD50 for EOM was approximately $500 \mathrm{mg} / \mathrm{kg}$ in mice. The essential oil induced increase of micronucleated erythrocytes only at $300 \mathrm{mg} / \mathrm{kg}$, suggesting moderate genotoxicity. EOM (100 or $150 \mathrm{mg} / \mathrm{kg}$ ) and fenchone $(60 \mathrm{mg} / \mathrm{kg}$ ) reduced all analyzed parameters (tumor volume and mass, and total viable cancer cells). Survival also increased for the treated animals with EOM and fenchone. For EOM $150 \mathrm{mg} / \mathrm{kg}$ and 5-FU treatment, most cells were arrested in the G0/G1 phase, whereas for fenchone, cells arrested in the $S$ phase, which represents a blockage in cell cycle progression. Regarding the toxicological evaluation, EOM induced weight loss, but did not induce hematological, biochemical or histological (liver and kidneys) toxicity. Fenchone induced decrease of AST and ALT, suggesting liver damage.
\end{abstract}

Conclusions: The data showed EOM caused in vivo cell growth inhibition on Ehrlich ascites carcinoma model by inducing cell cycle arrest, without major changes in the toxicity parameters evaluated. In addition, this activity was associated with the presence of fenchone, its major component.

Keywords: Mesosphaerum sidifolium, Lamiaceae, Fenchone, Hemolysis, Ehrlich ascites carcinoma, Genotoxicity

\footnotetext{
* Correspondence: mariannavbs@ltf.ufpb.br

${ }^{1}$ Programa de Pós-graduação em Produtos Naturais e Sintéticos Bioativos,

Centro de Ciências da Saúde, Universidade Federal da Paraíba, João Pessoa,

Paraíba 58051-970, Brazil

2Departamento de Ciências Farmacêuticas, Universidade Federal da Paraíba,

João Pessoa, Paraíba 58051-970, Brazil
}

(c) The Author(s). 2017 Open Access This article is distributed under the terms of the Creative Commons Attribution 4.0 International License (http://creativecommons.org/licenses/by/4.0/, which permits unrestricted use, distribution, and reproduction in any medium, provided you give appropriate credit to the original author(s) and the source, provide a link to the Creative Commons license, and indicate if changes were made. The Creative Commons Public Domain Dedication waiver (http://creativecommons.org/publicdomain/zero/1.0/) applies to the data made available in this article, unless otherwise stated. 


\section{Background}

Cancer is a group of diseases characterized by the uncontrolled cells growth and multiplication that can invade diverse tissues. In this context, carcinogenesis is a multistep process that begins with a transformation of normal cells into cancer cells, progresses with hyperproliferation and culminates in the acquisition of angiogenic properties, invasive potential, and establishment of metastatic lesions [1]. Nowadays, it is an important public health problem worldwide, since it is a leading cause of mortality and morbidity in the Western countries and the second leading cause of death in third world countries, thus imparting a significant societal burden $[2,3]$.

Natural products continue to be important source of cancer-fighting compounds [4]. Among them, essential oils from plants have been useful in cancer prevention and treatment [5-7]. Its effects are associated with antioxidant, antimutagenic, antiproliferative, and immunostimulatory properties, besides modulating multidrug resistance [8].

The family Lamiaceae is composed of herbs, shrubs and trees, with about 300 genera and 7500 species, having a cosmopolitan distribution, but mainly centered in the Mediterranean region, where is an integral part of the vegetation. In Brazil, there are 28 genera and about 350 species [9].

Mesosphaerum species have shown antimicrobiane [10, 11], antiulcer [12], antidepressive [13], anti-inflammatory and antinociceptive $[14,15]$, and antihypertensive activities [14]. Recent data showed that the Hyptis mutabilis aqueous extract has antitumor activity against sarcoma 180 (murine tumor), and low toxicity. It was also observed that its hexane extract showed moderate inhibition of Ehrlich solid tumor [16].

Mesosphaerum sidifolium (L'Hérit.) Harley \& J.F.B.Pastore (syn. Hyptis umbrosa) (Lamiaceae) is popularly known as "aleluia do serrote" [17] and "alfazema do mato" [18]. The most commonly used parts are the leaves and flowers. In folk medicine, $M$. sidifolium is used in stomach disorders and headaches treatment, besides of its use as expectorant, carminative and tonic [19]. However, there are few reports in the literature on $M$. sidifolium. This study determined the chemical composition, toxicity and anti-tumour activity of the essential oil from $M$. sidifolium aerial parts (EOM), and its major component.

\section{Methods}

\section{Drugs and reagents}

Propidium iodide (P4170 Sigma-Aldrich), 5-Fluorouracil (5-FU) (F6627 Sigma-Aldrich), Triton X-100 (93,443 Sigma-Aldrich), Tween 80 (P4780 Sigma-Aldrich), and cyclophosphamide (C7397 Sigma-Aldrich), Dimethylsulfoxide (DMSO) (67-68-5 Mallinckrodt Chemicals ${ }^{\oplus}$ ), Sodium thiopental (Thiopentax ${ }^{\oplus}$ ) was purchased from
Cristália (Itapira, SP, Brazil), and heparin (Parinex ${ }^{\odot}$ ) from Hipolabor (Sabará, MG, Brazil). Kits for biochemical and hematological analysis were purchased from LABTEST $^{\oplus}$ (ALT/GPT Liquiform ref.: 108; ALT/GPT Liquiform ref.:1008; Creatinina ref.: 35; Uréia CE ref.: 27) (Lagoa Santa, MG, Brazil). (+)-Fenchone (analytical standard) (46,208 Sigma-Aldrich).

\section{Plant material}

Aerial parts of Mesosphaerum sidifolium (L'Hérit.) Harley \& J.F.B.Pastore (syn. Hyptis umbrosa) were collected in July 2015 in Maturéia, Paraíba state, Brazil. The species was identified by Dr. Maria de Fatima Agra. Voucher specimen number AGRA 6964 was deposited at the Herbarium Lauro Pires Xavier at the Federal University of Paraíba, Brazil.

\section{Extraction of the essential oil}

The fresh leaves of $M$. sidifolium were submitted to hydrodistillation for $4 \mathrm{~h}$ using a Clevenger-type apparatus at $40{ }^{\circ} \mathrm{C}$. The oil obtained has a yellow color which was dried using anhydrous sodium sulfate and filtered afterwards. For further analysis, $2 \mu \mathrm{L}$ of the volatile oil obtained was dissolved in $1 \mathrm{~mL}$ of ethyl acetate.

\section{Analysis of essential oil}

The GC analysis was performed on a Shimadzu QP2000-PLUS-A gas chromatograph using fused silica capillary column DB-5 (30 mx $0.25 \mathrm{~mm}$ id, $0.25 \mathrm{mM}$ film thickness). Helium was used as carrier gas at a flow rate of $1.0 \mathrm{~mL} / \mathrm{min}$. The oven temperature was programmed from $60^{\circ}$ to $240^{\circ}$ at $3{ }^{\circ} \mathrm{C} / \mathrm{min}$. The injector and detector temperatures were $220{ }^{\circ} \mathrm{C}$ and $230{ }^{\circ} \mathrm{C}$, respectively.

\section{Gas chromatography - mass spectrometry (GC-MS)}

Analysis by Gas Chromatography - Mass Spectrometry (GC-MS) was performed on a Shimadzu QP2000-PLUS system-Quadrupole MS, operating with ionization energy of $70 \mathrm{eV}$ and fused silica capillary column DB-5 (30 mx $0.25 \mathrm{~mm}$ id, $0.25 \mathrm{mM}$ film thickness) with helium as a carrier gas at a flow rate of $1 \mathrm{~mL} / \mathrm{min}$ with a split. The temperatures of injector and detector were $220^{\circ} \mathrm{C}$ and $230{ }^{\circ} \mathrm{C}$, respectively. The column temperature was set from $60{ }^{\circ} \mathrm{C}$ to $240{ }^{\circ} \mathrm{C}$ at $3{ }^{\circ} \mathrm{C} / \mathrm{min}$. The substances identification was performed by comparing their mass spectra with the GCMS database (62 Nist Research Library) and Kovats retention index [20]. Retention rates of the compounds were obtained by coinjection of the essential oil with a standard mixture of hydrocarbons (C9-C24), applying the equation of Van den Dool \& Kratz [21]. 


\section{Tumor cell line}

Ehrlich carcinoma cell line was generously provided by Pharmacology and Toxicology Division, CPQBA, UNICAMP (Paulínia, SP, Brazil). The cells were maintained in the peritoneal cavities of Swiss mice in the Dr. Thomas George Bioterium (Research Institute in Drugs and Medicines/Federal University of Paraíba, Brazil).

\section{Animals}

Swiss albino mice (Mus musculus), females (27-31 g), obtained from the Dr. Thomas George Bioterium (Research Institute in Drugs and Medicines/Federal University of Paraíba, Brazil), were used. The animals were randomly housed in cages containing six animals with food and water ad libitum. All animals were kept on a $12 \mathrm{~h} / 12 \mathrm{~h}$ off light-dark cycle (lights on at 6:00 a.m.). All procedures were previously approved by the Animal Studies Committee from the Federal University of Paraíba (CEUA-UFPB, no. 0510/11).

\section{Pharmacological assays \\ Evaluation of cytotoxicity against mice erythrocytes}

EOM cytotoxicity activity and its major component was evaluated using mice erythrocytes [22]. Briefly, fresh blood samples were collected, and re-suspended in PBS to make a $0.5 \%(v / \mathrm{v})$ solution. Various concentrations of EOM $(0-1000 \mu \mathrm{g} / \mathrm{mL}$ for EOM, and $0-3000 \mu \mathrm{g} / \mathrm{mL}$ for its major component) dissolved in DMSO $(5 \% \mathrm{v} / \mathrm{v}$ in PBS), were added to the red blood cells suspension. The plates with the sample-erythrocyte mixtures were incubated in a mixer for $60 \mathrm{~min}$ and then centrifuged. The supernatant was carefully removed. After removal, $200 \mu \mathrm{L}$ of a solution of Triton X-100 (0.1\%) was added to each well containing the sample-erythrocyte mixtures and thoroughly stirred. The hemolysis caused was determined by spectrophotometry at $415 \mathrm{~nm}$. The concentration that produced 50\% hemolysis (HC50) was then determined. Positive control (100\% hemolysis), and negative control ( $0 \%$ hemolysis) incubated erythrocytes with $0.1 \%$ Triton $\mathrm{X}-100$ in PBS, and 5\% DMSO in PBS, respectively, were used.

\section{Evaluation of acute preclinical toxicity}

The evaluation of acute preclinical toxicity for EOM was performed based on the "Guidelines for Testing of Chemicals" $n^{\circ} 423$ from The Organisation for Economic Co-operation and Development [23]. Mice ( $n=3$ females/ group) were subjected to single doses of 300 or $2000 \mathrm{mg} / \mathrm{kg}$ of EOM intraperitoneally (i.p.), to the control group it was administered vehicle alone $(5 \%(v / v)$ Tween 80 in saline). For toxicity detection, suggestive signs of Central Nervous System (CNS), or Autonomic Nervous System (ANS) activity were recorded. Careful observation was performed at the intervals: $0,15,30$, and $60 \mathrm{~min}$, after $4 \mathrm{~h}$, and daily for 14 days. The dose responsible for the death of $50 \%$ of the experimental animals $\left(\mathrm{LD}_{50}\right)$ was estimated.

\section{Evaluation of genotoxicity}

For the micronucleus assay, female mice ( $n=5 /$ group) were treated (i.p.) with single dose of 150 or $300 \mathrm{mg} / \mathrm{kg}$ EOM [24]. A positive control group (cyclophosphamide at $50 \mathrm{mg} / \mathrm{kg}$ i.p.), and a negative control group (Tween 80 at $5 \%$ in saline), were included. After $48 \mathrm{~h}$, the animals were anesthetized with sodium thiopental $(40 \mathrm{mg} / \mathrm{kg})$, and peripheral blood samples were obtained from the tail $(10 \mu \mathrm{L})$, for the blood smears. For each animal, three blood smears were prepared, and a minimum of 2000 erythrocytes were counted to determine the number of micronucleated erythrocytes [25].

\section{Evaluation of in vivo antitumor activity}

Five to seven-day-old Ehrlich tumor cells, $0.5 \mathrm{~mL}$ at $2.0 \times 10^{6}$ cells $/ \mathrm{mL}$, were implanted in the peritoneal cavity of the female mice ( $n=6 /$ group) [26]. One day after inoculation, EOM (50, 100 or $150 \mathrm{mg} / \mathrm{kg}$ ) and its major component (30 or $60 \mathrm{mg} / \mathrm{kg}$ ) were dissolved in $5 \%(\mathrm{v} / \mathrm{v})$ Tween-80 in $0.9 \%(w / v) \mathrm{NaCl}$, and administered for nine consecutive days (i.p.). 5-FU (25 mg/ $\mathrm{kg}$ ) was used as a positive control. The healthy group (healthy mice) and tumor control group (mice bearing Ehrlich ascites carcinoma cells), were treated with $5 \%$ Tween- 80 in $0.9 \%$ $(w / v) \mathrm{NaCl}$. On the eleventh day, mice were kept fasting for $6 \mathrm{~h}$, and peripheral blood samples from all groups were collected from the retro-orbital plexus under light sodium thiopental anesthesia $(40 \mathrm{mg} / \mathrm{kg})$, the animals were then euthanized.

The volume of ascitic fluid collected from the peritoneal cavity was expressed in milliliter $(\mathrm{mL})$. It was determined the total viable cancer cells by trypan blue assay [26]. Tumor weights were measured by taking the mice's weights before and after the collection of the ascitic fluid from peritoneal cavity, and expressed in grams (g).

The remaining animals ( $n=6 /$ group) were kept alive with food and water ad libitum to calculate the animal's survival rates.

\section{Cell cycle analyses}

For the determination of cell cycle phase distribution, $10^{6}$ cells from ascitic fluid of treated animals (groups: tumor control; 50, 100 and $150 \mathrm{mg} / \mathrm{kg}$ EOM; 30 and $60 \mathrm{mg} / \mathrm{kg}$ major component) were centrifuged at $230 \mathrm{~g}$ for $7 \mathrm{~min}$. The supernatant was removed and the pellet was resuspended in $0.3 \mathrm{~mL}$ of hypotonic fluorocromic solution containing RNase $(0,5 \mathrm{mg} / \mathrm{mL})$, Triton-X $(0,25 \%)$ and propidium iodide (PI) $(0,25 \mathrm{mg} / \mathrm{mL})$. Then, the analysis was performed by cytometric flow 
Table 1 Chemical composition of essential oil from aerial parts of Mesosphaerum sidifolium

\begin{tabular}{|c|c|c|}
\hline Compounds & $\%$ relative & $\mathbb{R}$ \\
\hline a-pinene & 0.1 & 934 \\
\hline a-fenchene & 0.1 & 946 \\
\hline myrcene & 0.4 & 986 \\
\hline a-phellandrene & 1.3 & 100 \\
\hline limonene & 5.4 & 102 \\
\hline Y-terpinene & 0.1 & 105 \\
\hline terpinolene & 0.1 & 108 \\
\hline fenchone & 24.8 & 108 \\
\hline linalol & 0.2 & 109 \\
\hline endo-fenchol & 0.3 & 111 \\
\hline camphor & 0.7 & 114 \\
\hline borneol & 0.2 & 117 \\
\hline 4-terpineol & 0.4 & 117 \\
\hline a-terpineol & 0.5 & 119 \\
\hline geraniol & 0.1 & 124 \\
\hline bornyl acetate & 1.9 & 128 \\
\hline ¿-elemene & 2.0 & 132 \\
\hline a-cubebene & 0.1 & 137 \\
\hline a-copaene & 0.1 & 137 \\
\hline$\beta$-elemene & 0.8 & 138 \\
\hline a-gurjunene & 0.7 & 140 \\
\hline$\beta$-caryophyllene & 4.6 & 141 \\
\hline Y-elemene & 0.5 & 142 \\
\hline a-guaiene & 0.2 & 143 \\
\hline trans-muurola-3,5-diene & 0.3 & 144 \\
\hline a-humulene & 2.2 & 145 \\
\hline duaca-5,8-diene & 2.4 & 145 \\
\hline trans-cadina-1(6),4-diene & 0.5 & 145 \\
\hline 10-epi- $\beta$-acoradiene & 0.2 & 146 \\
\hline Y-gurjunene & 0.2 & 146 \\
\hline Y-muurolene & 0.3 & 147 \\
\hline germacrene D & 0.8 & 147 \\
\hline$\beta$-selineme & 0.2 & 148 \\
\hline trans-muurola-4(14),5-diene & 0.2 & 148 \\
\hline biciclogermacrene & 1.7 & 149 \\
\hline a-muurolene & 0.6 & 149 \\
\hline Y-cadinene & 1.0 & 150 \\
\hline cubebol & 6.9 & 151 \\
\hline$\delta$-cadinene & 1.8 & 152 \\
\hline a-cadinene & 0.2 & 153 \\
\hline a-calacorene & 0.1 & 154 \\
\hline elemol & 1.8 & 155 \\
\hline palustrol & 0.2 & 156 \\
\hline
\end{tabular}

Table 1 Chemical composition of essential oil from aerial parts of Mesosphaerum sidifolium (Continued)

\begin{tabular}{lll}
\hline spathullenol & 4.5 & 1572 \\
caryophyllene oxide & 0.3 & 1577 \\
globulol & 0.4 & 1589 \\
viridifloral & 0.1 & 1592 \\
guaiol & 0.1 & 1595 \\
ledol & 0.3 & 1599 \\
humulene epoxid II & 0.2 & 1604 \\
1,10-di-epi-cubebol & 0.2 & 1610 \\
10-epi-y-eudesmol & 0.5 & 1627 \\
alloaromadendrene epoxid & 0.2 & 1634 \\
epi-a-cadinol & 1.1 & 1637 \\
epi-a-muurolol & 1.4 & 1640 \\
a-muurolol & 0.4 & 1642 \\
a-cadinol & 4.7 & 1651 \\
shyobunol & 0.4 & 1687 \\
\hline
\end{tabular}

(BD FACSCalibur ${ }^{\circ}$, USA), a total of 10,000 events were obtained, and data were analyzed using WinMDI 2.9 software [27].

\section{Toxicity evaluation for transplanted mice}

Body weights were registered at the beginning and end of the treatment while the water and food consumption was evaluated daily for the nine days of the treatment. Liver, spleen, thymus, and kidneys were weighed for the determination of their organ indices [organ weight $(\mathrm{mg}) /$ animal weight $(\mathrm{g})]$. For biochemical analysis, serum samples were used to determine the levels of urea, creatinine, and the activities of alanine aminotransferase (ALT) and aspartate aminotransferase (AST). For the hematological analysis, heparinized whole blood was used to determine: hemoglobin $(\mathrm{Hb})$ level, red blood cell $(\mathrm{RBC})$ count, hematocrit (Hct), and the red cell indices mean corpuscular volume $(\mathrm{MCV})$, mean corpuscular hemoglobin $(\mathrm{MCH})$, and mean corpuscular hemoglobin concentration (MCHC) and, total and differential leukocyte counts. After weight determination and fixation in 10\% $(v / v)$ formaldehyde, portions of the livers and kidneys were cut into small pieces, then into sections of $3 \mu \mathrm{m}$, and stained with hematoxylin-eosin, and examined microscopically for lesions [28].

\section{Statistical analysis}

Data are presented as mean \pm SEM. The differences between experimental groups were compared by analysis of variance (ANOVA), followed by Tukey's test $(p<0.05)$. The HC50 value and their 95\% confidence intervals (CI 95\%) were obtained by nonlinear regression. For 
the genotoxicity evaluation it was used the MannWhitney $\mathrm{U}$ test $(p<0.05$ was considered significant).

\section{Results}

\section{Identification of volatile compounds in EOM}

The essential oil was obtained by hydro distillation from the leaves of $M$. sidifolium with a yield of $0.6 \%$ compared to the fresh weight of its botanical material. The total percentage of volatile components identified was of $92.9 \%$, comprising 57 components. The major compounds were fenchone $(24.8 \%)$, cubebol $(6.9 \%)$, limonene (5.4\%), spathulenol (4.5\%), $\beta$-caryophyllene (4.6\%) and $\alpha$ cadinol (4.7\%) (Table 1).

\section{Cytotoxicity against mice erythrocytes}

EOM displayed a concentration-dependent haemolytic effect. The mean HC50 was 494.9 (494.2-495.6) $\mu \mathrm{g} / \mathrm{mL}$. Differently, fenchone did not induce hemolytic effect up to $3000 \mu \mathrm{g} / \mathrm{mL}$ (Fig. 1).

\section{Acute preclinical toxicity}

EOM $300 \mathrm{mg} / \mathrm{kg}$ did not induce death. Following the guideline N. 423 from OECD, we repeated the test using three additional animals, with the same dose. Again, no death was observed. At $300 \mathrm{mg} / \mathrm{kg}$, EOM induced only weak toxicity signs, such as constipation and decreased urination, vocalization and hyperactivity, considered to be without clinical importance, since they disappeared after $60 \mathrm{~min}$ of administration. Then, we tested EOM $2000 \mathrm{mg} / \mathrm{kg}$ that induced severe symptoms and death of the three animals tested within the first minutes after treatment, therefore this dose was characterized as high toxicity (Table 2 ). The $\mathrm{LD}_{50}$ was estimated approximately in $500 \mathrm{mg} / \mathrm{kg}$.

\section{Genotoxicity}

EOM only in the highest dose $(300 \mathrm{mg} / \mathrm{kg})$ induced an increase in the number of micronucleated erythrocytes

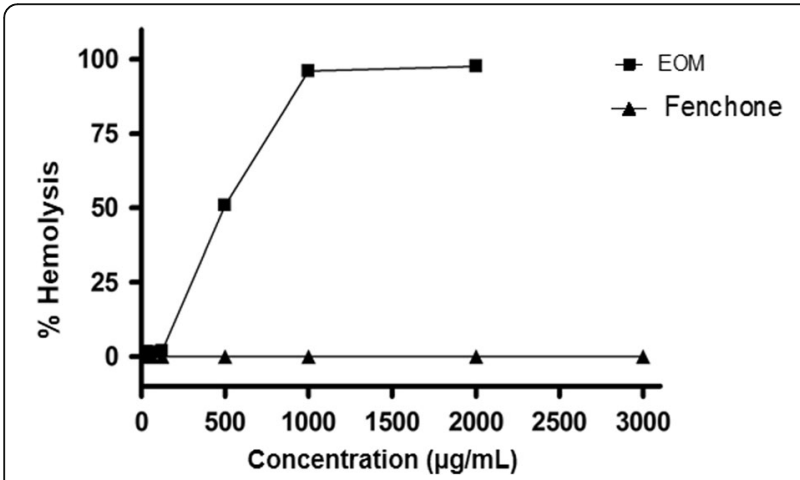

Fig. 1 Hemolysis percentage in red blood cells of Swiss mice after treatment with EOM $(\mu \mathrm{g} / \mathrm{mL})$. Each dot represents the average \pm SEM of three experiments with three replicates, with 95\% confidence interval
Table 2 Effect of single doses (i.p.) of EOM in mice $(n=3)$

\begin{tabular}{llll}
\hline Groups & Dose $(\mathrm{mg} / \mathrm{kg})$ & $\mathrm{D} / T^{*}$ & Symptoms \\
\hline Control & - & $0 / 3$ & None \\
EOM & 300 & $0 / 3$ & $\begin{array}{l}\text { Constipation and decreased } \\
\text { urination }\end{array}$ \\
EOM 300 & $0 / 3$ & $\begin{array}{l}\text { Decreased urination, Vocalization } \\
\text { and hyperactivity }\end{array}$ \\
EOM $\quad 2000$ & $3 / 3$ & $\begin{array}{l}\text { Tremors, convulsions, ataxia, loss of } \\
\text { corneal and auricular reflex, cyanosis, } \\
\text { loss of muscle tone and no force to grasp }\end{array}$ \\
\hline
\end{tabular}

${ }^{*} \mathrm{D} / \mathrm{T}=$ Number of dead mice/number of treated mice

in peripheral blood $(5.60 \pm 0.40)$, as compared to the control group $(2.80 \pm 0.37)$. As expected, cyclophosphamide induced an increase of number of micronucleated erythrocytes $(14.50 \pm 2.60)$ (Table 3$)$.

\section{In vivo antitumor activity}

EOM (100 and $150 \mathrm{mg} / \mathrm{kg}$ ) induced a significant decrease in tumor weight and volume, and tumor cell total count, when compared to the tumor control group. For fenchone $(60 \mathrm{mg} / \mathrm{kg})$, it was observed reduction in all analyzed parameters. Similar results were observed for the standard drug $(5-\mathrm{FU}, 25 \mathrm{mg} / \mathrm{kg})$. Data are shown in Table 4.

In addition, there was an increase in survival time of all of groups, when compared with the tumor control group, however this effect was more pronounced at $100 \mathrm{mg} / \mathrm{kg}$ EOM (Fig. 2a) and $60 \mathrm{mg} / \mathrm{kg}$ fenchone (Fig. 2b).

\section{Analysis of cell cycle}

EOM (100 and $150 \mathrm{mg} / \mathrm{kg}$ ) exhibited significant changes in the distribution of Ehrlich carcinoma cells at different stages of the cell cycle (Fig. 3a). The results show that EOM $100 \mathrm{mg} / \mathrm{kg}$ induced increase in the $\mathrm{S}$ phase (58.27\%), accompanied by the reduction in $\mathrm{G} 2 / \mathrm{M}$ phase (9.1\%). At the highest dose (150 mg/kg EOM), it was observed and increase in sub-G1 peak to $14.1 \%$ and in G0/ G1 phase (65.6\%), associated with descrease in $S$ and G2/M phases (13.7\% and 6.4\%, respectively). For 5-FU,

Table 3 Number of micronucleated erythrocytes in peripheral blood of mice treated with single doses of EOM and cyclophosphamide (i.p.) $(n=5)$

\begin{tabular}{lll}
\hline Groups & Dose $(\mathrm{mg} / \mathrm{kg})$ & $\begin{array}{l}\text { Number of micronucleated } \\
\text { erythrocytes }\end{array}$ \\
\hline Control & - & $2.8 \pm 0.4$ \\
Cyclophosphamide & 50 & $14.5 \pm 2.6^{\mathrm{a}}$ \\
EOM & 150 & $4.4 \pm 0.6$ \\
EOM & 300 & $5.6 \pm 0.4^{\mathrm{a}}$
\end{tabular}

Data are presented as mean \pm SEM of five animals analyzed by Mann-Whitney $\mathrm{U}$ test. ${ }^{\mathrm{a}} p<0.05$ compared to the control group 
Table 4 Effects of EOM, fenchone and 5-FU on tumor volume, weight, and total viable cancer cells in mice ( $n=6)$ transplanted with Ehrlich ascites carcinoma cells subjected to different treatments (9 days)

\begin{tabular}{|c|c|c|c|c|}
\hline Groups & Dose, $\mathrm{mg} / \mathrm{kg}$ & Tumor volume, mL & Tumor weight, g & Total viable cancer cells, $\times 10^{7}$ \\
\hline Tumor Control & - & $7.6 \pm 0.6$ & $11.9 \pm 0.9$ & $339.8 \pm 46.4$ \\
\hline $5-\mathrm{FU}$ & 25 & $0.1 \pm 0.0^{\mathrm{a}}$ & $2.3 \pm 1.0^{\mathrm{a}}$ & $8.5 \pm 2.3^{a}$ \\
\hline EOM & 50 & $4.9 \pm 2.2$ & $12.1 \pm 1.3$ & $120.1 \pm 18.9$ \\
\hline EOM & 100 & $0.0 \pm 0.0^{\mathrm{a}}$ & $0.8 \pm 0.4^{\mathrm{a}}$ & $4.4 \pm 1.8^{\mathrm{a}}$ \\
\hline EOM & 150 & $0.0 \pm 0.0^{\mathrm{a}}$ & $1.3 \pm 0.2^{\mathrm{a}}$ & $6.9 \pm 4.1^{\mathrm{a}}$ \\
\hline Fenchone & 30 & $5.5 \pm 1.0$ & $8.4 \pm 1.0$ & $228.0 \pm 39.9$ \\
\hline Fenchone & 60 & $0.8 \pm 0.6^{a}$ & $3.9 \pm 0.9^{\mathrm{a}}$ & $10.9 \pm 4.1^{\mathrm{a}}$ \\
\hline
\end{tabular}

Data presented as mean \pm SEM of six animals analyzed by ANOVA followed by Tukey test. ${ }^{a} p<0.05$ compared to tumor control

G0/G1 arrest was observed (84.3\%), accompanied by the reduction in $\mathrm{S}(8.4 \%)$ and $\mathrm{G} 2 / \mathrm{M}(4.8 \%)$ phases.

Fenchone also induced changes on cell cycle. There was an increase in $\mathrm{S}$ phase to $75.8 \%$, associated with decrease in G2/M (3.5\%) and G0/G1 (17.8\%) phases (Fig. 3b).

\section{Toxicity evaluation for transplanted mice}

EOM $(50 \mathrm{mg} / \mathrm{kg}$ ) produced an increase on water consumption, whereas at $150 \mathrm{mg} / \mathrm{kg}$ there was a decrease on feed consumption, when compared to respective healthy and tumor control groups. In addition, EOM $(100$ and $150 \mathrm{mg} / \mathrm{kg})$ and 5-FU induced significant weight loss in the experimental animals after nine days of treatment. For fenchone (30 and $60 \mathrm{mg} / \mathrm{kg}$ ), there was only an increase on water consumption (Table 5). In relation to organs index, there was an increase in liver index for tumor control group comparing with health animals; however, EOM reduced this parameter in relation to tumor control group. Fenchone did not restore the normal values for liver index. In addition, fenchone induced an increase in heart and thymus indexes (Table 6).

EOM induced no significant changes for AST and ALT activity levels. At $150 \mathrm{mg} / \mathrm{kg}$ there was only an increase in urea levels, without changes for creatinine levels. On the other hand, fenchone induced significant decrease in liver function parameters, AST and ALT (Table 7).

Regarding hematological evaluation, changes were observed in tumor control group, comparing with health animals, which included a decrease in red blood cells, hemoglobin and hematocrit. In contrast, EOM increased these parameters in relation to tumor control group, but these values remained as health animals. In addition, there was a leukemoid reaction in tumor control group; nevertheless, EOM (100 or $150 \mathrm{mg} / \mathrm{kg}$ ) and 5-FU induced a significant reduction in this parameter. Yet, 5FU induced lymphocyte increase and neutrophil count reduction compared to the tumor control group (Table 8). For fenchone, there was a re-established of the blood count parameters as health animals, comparing to the tumor control group. Similar to EOM, fenchone induced a significant reduction in total leukocytes number (Table 9).

No histopathological changes were observed in the kidneys of animals treated with EOM (Data not shown). The histopathological analysis of the livers showed a discrete, reactive lymphocytic, with rare and focal hepatocitolytic activity after treatment with EOM. It was also observed the presence of neutrocyte portite and capsulitis, besides hepatic tissue necrosis (Fig. 4a e b). In addition to these observations, also detected in the
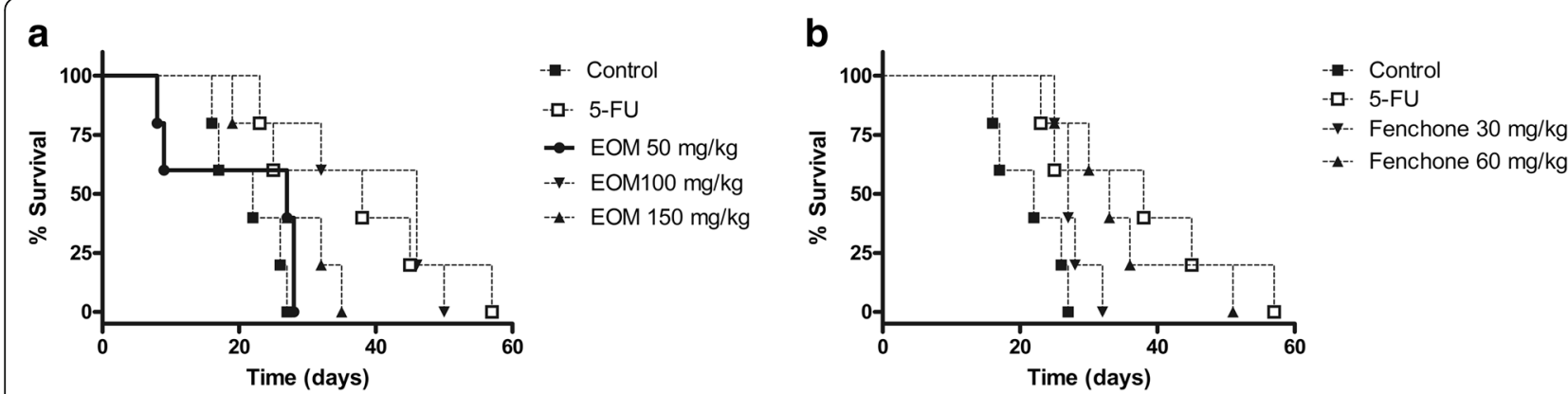

Fig. 2 Survival times of female mice inoculated with Ehrlich carcinoma cells and treated with EOM (a) and Fenchone (b). Data presented as mean \pm SEM of six animals analyzed by Kaplan-Meier test 

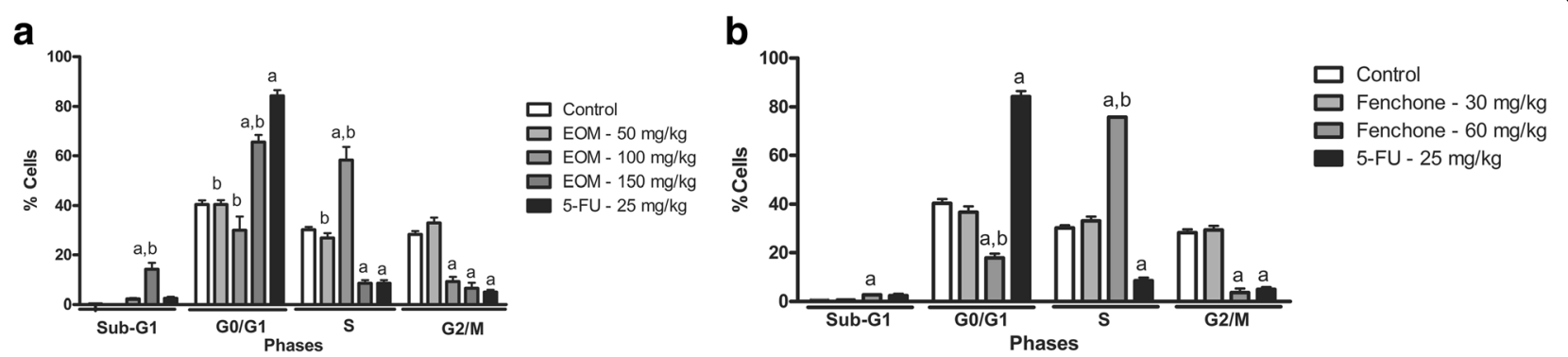

Fig. 3 Percentage of Ehrlich ascites carcinoma cells in different phases of the cell cycle after treatment with $5 \%$ Tween 80 solution (tumor control), 5-FU (25 mg/kg), EOM (50, 100 and $150 \mathrm{mg} / \mathrm{kg}$ ) (a) and Fenchone (30 and $60 \mathrm{mg} / \mathrm{kg})$ (b). Data presented as mean \pm SEM of six animals analyzed by ANOVA followed by Tukey test. ${ }^{a} p<0.05$ compared to tumor control. ${ }^{b} p<0.05$ compared to 5 -FU

tumor control group, the liver of animals treated with EOM presented mild hyperplasia of Kuppfer cells (Fig. 4c). Animals treated with 5-FU experienced hepatic damage greater than those treated with the highest doses of EOM (Fig. 4d).

\section{Discussion}

There are few data in the literature on the chemistry and pharmacology of the genus Mesosphaerum, and no reports were founded about Mesosphaerum sidifolium yet. The chemical composition described here for EOM is consistent with literature data for volatile constituents from Hyptis species [29]. The major component was the bicyclic terpenoid fenchone, which has not reports on antitumor activity. Then, herein we presented the toxicity and antitumor activity of EOM and fenchone.

Anaemia is the most common haematological cancer problem. Considering that chemotherapy can worsen the clinical situation, and this effect can be associated with the hemolysis and/or the inability of the bone marrow to make these cells [30], the cytotoxicity assay with erythrocytes is used to evaluate new drugs toxicity. Natural product due to not presenting hemolytic activity should present $\mathrm{CH} 50$ higher than $1250 \mu \mathrm{g} / \mathrm{mL}$ [31]. Then, EOM showed moderate cytotoxic effect in erythrocytes. In contrast, fenchone was considered low toxicity in mice's erythrocytes. Moreover, studies have documented that essential oils and their chemical constituents may have hemolytic effects [32]. This activity has been primarily related to their ability to interact with the cell membrane due to their lipophilic properties, which alter permeability, promoting hemolysis [33].

The in vivo EOM effects were investigated by acute preclinical toxicology assay, with the aim to establish safe doses to be used in in vivo pharmacological assays. The results showed that EOM has moderate acute toxicity, considering its $\mathrm{LD}_{50}$ value $500 \mathrm{mg} / \mathrm{kg}$. In general, if the $\mathrm{LD}_{50}$ of the drug is three times more than the minimum effective dose, the substance is considered a good candidate for further studies [34, 35]. Therefore, we used $150 \mathrm{mg} / \mathrm{kg}$ of EOM as the highest dose for testing. For fenchone, the dose levels were chosen considering the fenchone percentage in the EOM.

Genotoxicity assays are important for identifying potential carcinogens and mutagens [36]. The micronucleus test has been widely used to test the genotoxicity of several samples, including natural products [37].

Table 5 Feed and water consumption and weight of animals $(n=6)$ subjected to different treatments (9 days)

\begin{tabular}{lllll}
\hline Groups & Dose, $\mathrm{mg} / \mathrm{kg}$ & Water consumption, $\mathrm{ml}$ & Feed consumption, $\mathrm{g}$ & Gain/loss of weight, \% \\
\hline Healthy animals & - & $35.6 \pm 1.1$ & $30.9 \pm 1.6$ & $12.79 \pm 3.0$ \\
Tumor control & - & $34.6 \pm 2.1$ & $29.3 \pm 1.5$ & $11.3 \pm 1.1$ \\
5 -FU & 25 & $29.4 \pm 1.8$ & $32.8 \pm 1.2$ & $-10.1 \pm 1.2^{\mathrm{a}, \mathrm{b}}$ \\
EOM & 50 & $47.2 \pm 2.3^{\mathrm{a}, \mathrm{b}}$ & $33.9 \pm 2.9$ & $17.3 \pm 4.7^{\mathrm{c}}$ \\
EOM & 100 & $32.5 \pm 1.6$ & $30.8 \pm 1.6$ & $-8.6 \pm 4.3^{\mathrm{a}, \mathrm{b}}$ \\
EOM & 150 & $29.4 \pm 2.7$ & $23.3 \pm 2.1^{\mathrm{a}}$ & $-12.9 \pm 1.9^{\mathrm{a}, \mathrm{b}}$ \\
Fenchone & 30 & $42.2 \pm 1.0^{\mathrm{a}, \mathrm{b}, \mathrm{c}}$ & $35.6 \pm 0.8$ & $5.6 \pm 0.9^{c}$ \\
Fenchone & 60 & $46.6 \pm 1.6^{\mathrm{a}, \mathrm{b}, \mathrm{c}}$ & $35.3 \pm 0.1$ & $10.23 \pm 3.4^{c}$ \\
\hline
\end{tabular}

Data presented as mean \pm SEM of six animals analyzed by ANOVA followed by Tukey test. ${ }^{a} p<0.05$ compared to tumor control. ${ }^{b} p<0.05$ compared to healthy animals. ' $p<0,05$ compared to $25 \mathrm{mg} / \mathrm{kg} \mathrm{5-FU} \mathrm{group} \mathrm{by} \mathrm{ANOVA} \mathrm{followed} \mathrm{by} \mathrm{Tukey}$ 
Table 6 Effects of EOM, fenchone and 5-FU in the mice organ indices ( $n=6$ ) subjected to different treatments (9 days)

\begin{tabular}{|c|c|c|c|c|c|c|}
\hline Groups & Dose, mg/kg & Heart index, mg/g & Liver index, mg/g & Kidneys index, mg/g & Thymus index, mg/g & Spleen index, mg/g \\
\hline Healthy animals & - & $4.2 \pm 0.3$ & $50.8 \pm 2.0$ & $10.9 \pm 0.5$ & $3.7 \pm 0.5$ & $5.5 \pm 0.5$ \\
\hline Tumor control & - & $3.5 \pm 0.2$ & $71.2 \pm 3.1^{b}$ & $10.6 \pm 0.3$ & $2.5 \pm 0.2$ & $5.7 \pm 0.7$ \\
\hline 5-FU & 25 & $4.8 \pm 0.5$ & $57.4 \pm 1.9^{a}$ & $12.3 \pm 0.3$ & $2.9 \pm 0.0$ & $6.3 \pm 0.5$ \\
\hline EOM & 50 & $3.2 \pm 0.5$ & $59.3 \pm 2.9^{a}$ & $9.0 \pm 0.7$ & $2.6 \pm 0.6$ & $6.5 \pm 1.6$ \\
\hline EOM & 100 & $4.0 \pm 0.1$ & $55.8 \pm 1.6^{a}$ & $11.5 \pm 0.4$ & $3.6 \pm 0.4$ & $7.1 \pm 0.4$ \\
\hline EOM & 150 & $4.2 \pm 0.2$ & $56.8 \pm 3.0^{\mathrm{a}}$ & $11.6 \pm 0.9$ & $2.4 \pm 0.2$ & $7.4 \pm 1.2$ \\
\hline Fenchone & 30 & $4.0 \pm 0,2$ & $71.4 \pm 6.3^{b}$ & $11.0 \pm 0.7$ & $4.1 \pm 0.2^{a, c}$ & $8.9 \pm 1.3$ \\
\hline Fenchone & 60 & $4.7 \pm 0.4^{\mathrm{a}}$ & $75.6 \pm 1.4^{\mathrm{b}, \mathrm{c}}$ & $13.4 \pm 1.0$ & $3.5 \pm 0.3$ & $7.9 \pm 0.7$ \\
\hline
\end{tabular}

Data presented as mean \pm SEM of six animals analyzed by ANOVA followed by Tukey test. ${ }^{a} p<0.05$ compared to tumor control. ${ }^{b} p<0.05$ compared to healthy animals. ${ }^{c} p<0,05$ compared to $25 \mathrm{mg} / \mathrm{kg} 5$-FU group by ANOVA followed by Tukey

Considering that EOM induced increase in micronucleated erythrocytes number only at a dose level two times higher than the antitumor therapeutic dose, it was considered as low toxicity.

In recent decades, several animal models have been developed to investigate the in vivo antitumor activity of new drugs. Here, we used Ehrlich ascites carcinoma cells which is referred to as an undifferentiated carcinoma, and is originally hyperdiploid, has high transplantable capability, no-regression, rapid proliferation, shorter life span, $100 \%$ malignancy and does not have tumor specific transplantation antigen [37]. EOM $(100$ and $150 \mathrm{mg} / \mathrm{kg})$ and fenchone $(60 \mathrm{mg} / \mathrm{kg})$ reduced all analyzed parameters (tumor volume and mass, and total viable cancer cells).

The main goal of cancer treatment is to eradicate the disease. However, in situations where cure is impossible, the focus is on improving symptoms and preserving quality of life associated with increased patient survival. New chemotherapeutic agents are associated with increased survival in patients with some types of cancer [38]. In this context, EOM and fenchone induced an important increase in the survival of the animals exposed. Considering that there was no significant difference in the effect of 100 and $150 \mathrm{mg} / \mathrm{kg}$ EOM in the parameters tumor volume and weight, and total viable cancer cells, and both doses had similar toxicity profile, we have shown the advantages of $100 \mathrm{mg} / \mathrm{kg}$ EOM.

Many anticancer drugs have been isolated from plant species or are based on such substances. In addition, essential oils and their components, especially monoterpenes and phenylpropanoids, have shown antitumor activity $[5-7,39,40]$. Some of the constituents present in EOM are described in the literature as having significant antitumor activity, specifically limonene [41], $\beta$-caryophyllene [42].

It is known that cell cycle dysregulation is one of the main characteristics of tumor cells [43]. The induction to the cell cycle arrest has been considered as an important mechanism of the drugs involved in the anticancer treatment [44-46].

For EOM $150 \mathrm{mg} / \mathrm{kg}$ and 5-FU treatment, most cells were arrested in the G0/G1 phase, whereas for fenchone, cells arrested in the $\mathrm{S}$ phase, which represents a blockage in cell cycle progression. As described in the literature, cell cycle arrest in G0/G1 gives the cells time to repair

Table 7 Effects of EOM, fenchone and 5-FU on biochemical parameters of peripheral blood of mice ( $n=6)$ subjected to different treatments (9 days)

\begin{tabular}{llllll}
\hline Groups & Dose, $\mathrm{mg} / \mathrm{kg}$ & $\mathrm{AST}, \mathrm{U} / \mathrm{L}$ & $\mathrm{ALT}, \mathrm{U} / \mathrm{L}$ & Urea, $\mathrm{mg} / \mathrm{dL}$ & $\mathrm{Creatinine,} \mathrm{mg} / \mathrm{dL}$ \\
\hline Healthy animals & - & $283.2 \pm 24.9$ & $53.6 \pm 6.55$ & $39.0 \pm 1.9$ & $0.4 \pm 0.0$ \\
Tumor control & - & $242.0 \pm 12.2$ & $67,80 \pm 7,11$ & $43.0 \pm 7.1$ & $0.3 \pm 0.0$ \\
$5-\mathrm{FU}$ & 25 & $199.3 \pm 38.4$ & $39.00 \pm 9.51$ & $33.2 \pm 1.5$ & $0.51 \pm 0.02$ \\
EOM & 50 & $217.4 \pm 27.4$ & $53.8 \pm 11,81$ & $27.5 \pm 12.0$ & $0.2 \pm 0.0$ \\
EOM & 100 & $285.4 \pm 22.1$ & $60.3 \pm 1.43$ & $45.9 \pm 5.7$ & $0.2 \pm 0.0$ \\
EOM & 150 & $320.2 \pm 73.9$ & $44.0 \pm 6.86$ & $81.8 \pm 8.4^{\mathrm{a}, \mathrm{b}}$ & $0.6 \pm 0.2$ \\
Fenchone & 30 & $155.8 \pm 7.5^{\mathrm{a}, \mathrm{b}}$ & $29,25 \pm 2,68^{\mathrm{a}}$ & $38.8 \pm 3.8$ & $0.3 \pm 0.0$ \\
Fenchone & 60 & $163.8 \pm 8.5^{\mathrm{a}, \mathrm{b}}$ & $34.6 \pm 5.4^{\mathrm{a}}$ & $37.8 \pm 2.4$ & $0.2 \pm 0.0$ \\
\hline
\end{tabular}

Data presented as mean \pm SEM of six animals analyzed by ANOVA followed by Tukey test. ${ }^{a} p<0.05$ compared to tumor control. ${ }^{b} p<0.05$ compared to healthy animals by ANOVA followed by Tukey 
Table 8 Effects of EOM and 5-FU on hematological parameters of peripheral blood of mice $(n=6)$ subjected to different treatments (9 days)

\begin{tabular}{|c|c|c|c|c|c|c|}
\hline \multirow[t]{2}{*}{ Parameters } & \multirow[t]{2}{*}{ Healthy animals } & \multirow[t]{2}{*}{ Tumor control } & \multicolumn{2}{|l|}{ 5-FU } & \multicolumn{2}{|l|}{ EOM } \\
\hline & & & $25 \mathrm{mg} / \mathrm{kg}$ & 50 mg/kg & $100 \mathrm{mg} / \mathrm{kg}$ & $150 \mathrm{mg} / \mathrm{kg}$ \\
\hline Red blood cells, $10^{6} / \mathrm{mm}^{3}$ & $9.3 \pm 0.1$ & $5.8 \pm 0.4^{b}$ & $9.7 \pm 0.2^{\mathrm{a}}$ & $6.9 \pm 0.1$ & $8.1 \pm 0.2^{a}$ & $9.0 \pm 0.3^{\mathrm{a}}$ \\
\hline Hemoglobin, g/dL & $14.8 \pm 0.2$ & $9.4 \pm 0.6^{b}$ & $14.9 \pm 0.4^{\mathrm{a}}$ & $10.2 \pm 0.7$ & $13.4 \pm 0.3^{\mathrm{a}}$ & $14.7 \pm 0.7^{\mathrm{a}}$ \\
\hline Hematocrit, \% & $43.8 \pm 0.5$ & $29.0 \pm 1.8^{b}$ & $46.6 \pm 1.0^{\mathrm{a}}$ & $40.0 \pm 1.6^{a}$ & $43.8 \pm 1.4^{a}$ & $44.2 \pm 2.1^{\mathrm{a}}$ \\
\hline $\mathrm{MCV}, \mathrm{fm}^{3}$ & $46.6 \pm 1.0$ & $49.8 \pm 0.6$ & $49.0 \pm 0.6$ & $57.6 \pm 2.2^{a, b}$ & $55.6 \pm 1.0^{a, b}$ & $48.8 \pm 0.6$ \\
\hline $\mathrm{MCH}, \mathrm{pg}$ & $15.8 \pm 0.5$ & $16.0 \pm 0.1$ & $15.4 \pm 0.2$ & $14.8 \pm 1.1$ & $17.0 \pm 0.2$ & $16.2 \pm 0.3$ \\
\hline $\mathrm{MCHC}, \mathrm{g} / \mathrm{dL}$ & $33.7 \pm 0.3$ & $34.5 \pm 0.8$ & $31.3 \pm 0.2$ & $25.7 \pm 1.6^{\mathrm{a}, \mathrm{b}}$ & $30.7 \pm 0.3$ & $33.2 \pm 0.6$ \\
\hline Total leukocytes, $10^{3} / \mathrm{mm}^{3}$ & $8.1 \pm 0.4$ & $15.1 \pm 1.1^{b}$ & $3.2 \pm 0.1^{\mathrm{a}}$ & $29.8 \pm 8.7^{\mathrm{a}, \mathrm{b}}$ & $3.1 \pm 0.4^{\mathrm{a}}$ & $5.0 \pm 1.6^{\mathrm{a}}$ \\
\hline Lymphocytes, \% & $60.6 \pm 4.2$ & $52.4 \pm 12.7$ & $90.4 \pm 0.9^{a}$ & $43.6 \pm 9.4$ & $56.6 \pm 2.1$ & $51.2 \pm 11.9$ \\
\hline Neutrophils, \% & $34.6 \pm 4.2$ & $45.4 \pm 12.4$ & $7.0 \pm 0.7^{\mathrm{a}}$ & $46.6 \pm 8.8$ & $35.6 \pm 2.9$ & $47.4 \pm 13.9$ \\
\hline Monocytes, \% & $4.4 \pm 0.7$ & $2.0 \pm 0.5$ & $2.6 \pm 0.7$ & $4.0 \pm 0.6$ & $2.4 \pm 0.5$ & $3.4 \pm 0.4$ \\
\hline Eosinophils, \% & $0.4 \pm 0.2$ & $0.2 \pm 0.2$ & $0.0 \pm 0.2$ & $0.2 \pm 0.2$ & $0.0 \pm 0.0$ & $0.0 \pm 0.0$ \\
\hline
\end{tabular}

Data are presented as mean \pm SEM of six animals analyzed by ANOVA followed by Tukey test. ${ }^{a} p<0.05$ compared to tumor control; ${ }^{b} p<0.05$ compared to healthy animals by ANOVA followed by Tukey

damage before DNA replication occurs or activating the apoptotic pathway [47]. Furthermore, the essential oil and fenchone at the higher doses induced a significant increase in the sub-diploid population (sub-G1 peak), which is considered as a marker of cell death by apoptosis [48]. The results of the cell cycle analysis corroborate the study of the mechanism of action of many essential oils and their components that stop the cell cycle in the G0/G1 [6] and S phase.

It is well-reported in the literature that the use of antineoplastic drugs can produce numerous adverse effects. Therefore, the use of tests that evaluate possible alterations of the organism homeostasis exposed to chemotherapy is essential. Repeated dose treatment (nine days) differs from the acute toxicity test because it allows evaluating the effects produced by the drug accumulation in the body. According to the results obtained, it is possible to suggest that fenchone exerts weak toxicity considering metabolic parameters, as feed and water consumption, and organ index, since it induced point changes. Regarding EOM, the data show that the essential oil and 5-FU induced weight loss, which is an adverse effect known to many antineoplasic drugs. It was observed an increase in liver index in tumor control

Table 9 Effects of fenchone and 5-FU on hematological parameters of peripheral blood of mice $(n=6)$ subjected to different treatments (9 days)

\begin{tabular}{|c|c|c|c|c|c|}
\hline \multirow[t]{2}{*}{ Parameters } & \multirow[t]{2}{*}{ Healthy animals } & \multirow[t]{2}{*}{ Tumor control } & \multirow{2}{*}{$\begin{array}{l}5-\mathrm{FU} \\
25 \mathrm{mg} / \mathrm{kg}\end{array}$} & \multicolumn{2}{|l|}{ Fenchone } \\
\hline & & & & $30 \mathrm{mg} / \mathrm{kg}$ & $60 \mathrm{mg} / \mathrm{kg}$ \\
\hline Red blood cells, $10^{6} / \mathrm{mm}^{3}$ & $9.3 \pm 0.1$ & $5.8 \pm 0.4^{b}$ & $9.7 \pm 0.2^{a}$ & $6.9 \pm 0.4^{\mathrm{b}, \mathrm{c}}$ & $8.0 \pm 0.4^{a}$ \\
\hline Hemoglobin, g/dL & $14.8 \pm 0.2$ & $9.4 \pm 0.6^{b}$ & $14.9 \pm 0.4^{\mathrm{a}}$ & $12.0 \pm 0.33^{\mathrm{a}, \mathrm{b}, \mathrm{c}}$ & $13.3 \pm 0.6$ \\
\hline Hematocrit, \% & $43.8 \pm 0.5$ & $29.0 \pm 1.8^{b}$ & $46.6 \pm 1.0^{\mathrm{a}}$ & $40.2 \pm 0.9^{a}$ & $45.2 \pm 3.3^{\mathrm{a}}$ \\
\hline $\mathrm{MCV}, \mathrm{fm}^{3}$ & $46.6 \pm 1.0$ & $49.8 \pm 0.6$ & $49.0 \pm 0.6$ & $59.0 \pm 3.5^{\mathrm{a}, \mathrm{b}, \mathrm{c}}$ & $59.2 \pm 2.2^{a, b, c}$ \\
\hline $\mathrm{MCH}, \mathrm{pg}$ & $15.8 \pm 0.5$ & $16.0 \pm 0.1$ & $15.4 \pm 0.2$ & $17.2 \pm 0.2^{a, b, c}$ & $16.6 \pm 0.3$ \\
\hline $\mathrm{MCHC}, \mathrm{g} / \mathrm{dL}$ & $33.7 \pm 0.3$ & $34.5 \pm 0.8$ & $31.3 \pm 0.2$ & $28.4 \pm 0.9^{a, b}$ & $31.0 \pm 0.7$ \\
\hline Total leukocytes, $10^{3} / \mathrm{mm}^{3}$ & $8.1 \pm 0.4$ & $15.1 \pm 1.1^{\mathrm{b}}$ & $3.2 \pm 0.1^{a}$ & $20.2 \pm 1.4^{a, b, c}$ & $4.0 \pm 0.6^{a}$ \\
\hline Lymphocytes, \% & $60.6 \pm 4.2$ & $52.4 \pm 12.7$ & $90.4 \pm 0.9^{\mathrm{a}}$ & $41.6 \pm 8.4^{c}$ & $64.6 \pm 5.6$ \\
\hline Neutrophils, \% & $34.6 \pm 4.2$ & $45.4 \pm 12.4$ & $7.0 \pm 0.7^{\mathrm{a}}$ & $52.8 \pm 8.6^{c}$ & $30.0 \pm .5 .4$ \\
\hline Monocytes, \% & $4.4 \pm 0.7$ & $2.0 \pm 0.5$ & $2.6 \pm 0.7$ & $2.0 \pm 0.5$ & $1.4 \pm 05^{b}$ \\
\hline Eosinophils, \% & $0.4 \pm 0.2$ & $0.2 \pm 0.2$ & $0.0 \pm 0.2$ & $0.0 \pm 0.0$ & $0.0 \pm 0.0$ \\
\hline
\end{tabular}

Data are presented as mean \pm SEM of six animals analyzed by ANOVA followed by Tukey test. ${ }^{a} p<0.05$ compared to tumor control; ${ }^{b} p<0.05$ compared to healthy animals. ${ }^{c} p<0,05$ compared To the group treated with $25 \mathrm{mg} / \mathrm{kg}$ of 5-FU by ANOVA followed by Tukey 


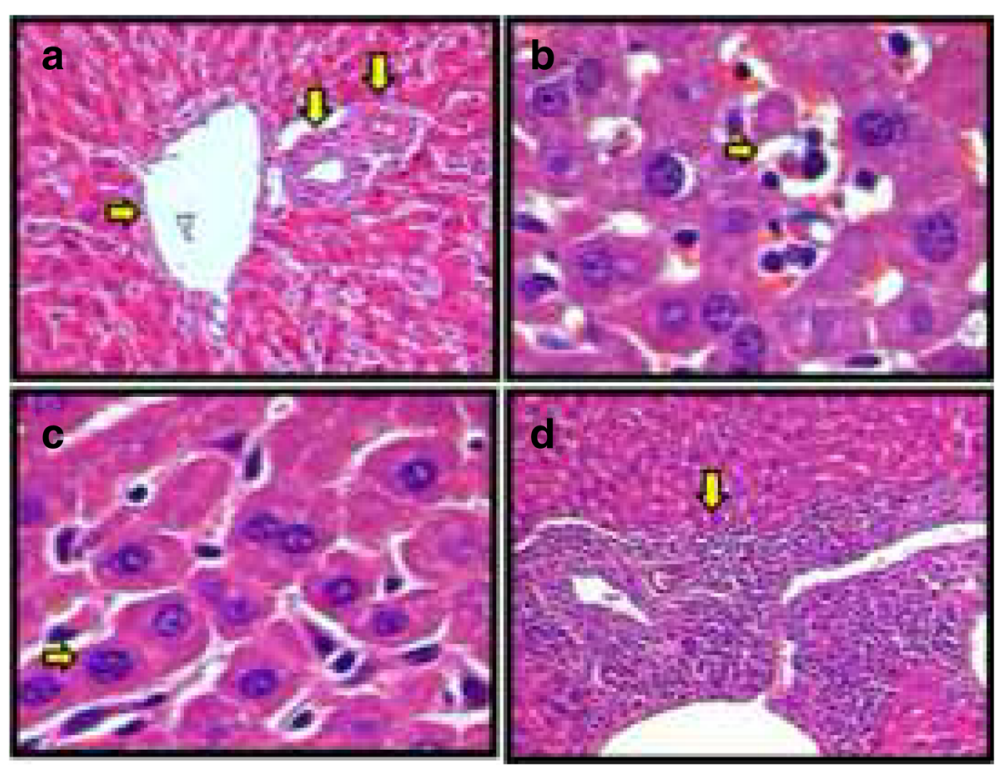

Fig. 4 Histopathology of the livers from the different experimental groups: (a) Mesosphaerum sidifolium essential oil (EOM) (50 mg/kg) - Portal space with a vasculobiliar triad; (b) EOM (150 mg/kg) - Anaplastic tumor cells, bordered by necrosis of the hepatic tissue; (c) EOM (100 mg/kg) Reactive hyperplasia of Kuppfer cells; (d) 5 -FU (25 mg/kg) - Lymphocytes at the moderate level compromising the portal space. Hematoxylin$\operatorname{eosin}(100$ or $400 \mathrm{x})$

group, which was associated with a reactive liver as consequence of tumor implantation in peritoneal cavity. However, EOM, but not fenchone, induced a decrease in liver index, restoring the normality as healthy animals.

Biochemical parameters were evaluated in order to investigate the renal and liver function. The data show EOM induced no toxicity, since the only change observed on urea levels has not clinical significance because the creatinine level was normal. For fenchone, the decrease in liver enzymes (AST and ALT) levels suggest hepatic damage, since severe and persistent changes such as fibrosis may produce little hepatocellular extravasation, resulting in normal or decreased levels of these enzymes $[49,50]$. However, additional studies of liver function and histology should be performed to clarify that effect.

Concerning the hematological parameters, it was observed that the tumor implantation alone was able to induce anemia, which is a cancer characteristic. EOM and fenchone reversed this effect, reestablishing the normal levels of blood counts, showing that these natural products even in the presence of the tumor do not interfere with these parameters and therefore does not induce toxicity at the blood cell level as well as hematopoiesis. Inoculation of the tumor alone causes a leukemoid reaction in the transplanted animals, which can be observed by the increase of total leukocytes in the transplanted control compared to the healthy one. These data corroborate with literature data that describe this type of reaction in the presence of the tumor [51-54]. Nevertheless, EOM and fechone, as 5-FU, induced immunosuppression associated with reduction on total leukocytes number, but this effect is not limiting for its study because most of the antineoplasic drugs induce this effect.

In this study, the histopathological findings for the kidneys support the idea that EOM has low renal toxicity, agreeing to biochemical data. In the liver, the changes observed in the animals treated with EOM were characteristic of systemic neoplastic disease with repercussion in the liver, considering the implantation of tumor cells in peritoneal cavity. However, some studies have shown that these changes occurring in all treated groups are related to poor hepatotoxicity, and drug withdrawal or dose adjustment usually leads to rapid improvement and damage reversal $[55,56]$.

\section{Conclusions}

Considering all data showed EOM caused in vivo cell growth inhibition on Ehrlich ascites carcinoma model by inducing cell cycle arrest, and this activity was associated with the presence of fenchone, its major component. Regarding to toxicological parameters, EOM induced weak toxicity considering biochemical and histological parameters, and induced immunosuppression. For fenchone, the data showed hepatotoxicity and immunosuppression, which is the most common undesirable effect of antineoplasic drugs. 


\section{Abbreviations}

5-FU: 5-Fluorouracil; ALT: Alanine aminotransferase; ANS: Autonomic Nervous System; AST: Aspartate aminotransferase; CEUA: Animal Ethics Committee; Cl: Confidence Interval; CNS: Central Nervous System; DMSO: Dimethylsulfoxide; EOM: Mesosphaerum sidifolium essential oil; GC: Gas Cromatography; GCMS: Gas Chromatography - Mass Spectrometry; Hb: Hemoglobin level; $\mathrm{HC}_{50}$ : Concentration producing 50\% hemolysis; Hct: Hematocrit; i.p.: Intraperitoneal route; $\mathrm{LD}_{50}$ : Dose responsible for the death of $50 \%$ of the experimental animals; MCH: Mean corpuscular hemoglobin; MCHC: Mean corpuscular hemoglobin concentration; MCV: Mean corpuscular volume; PBS: Phosphate-buffered saline; RBC: Red blood cell count; UFPB: Federal University of Paraíba

\section{Acknowledgements}

This work was supported by the Brazilian agencies Coordenação de Aperfeiçoamento de Pessoal de Nível Superior (CAPES) and Conselho Nacional de Desenvolvimento Científico e Tecnológico (CNPq). Pontual traduções (Londrina/Paraná/Brazil) performed English editing of the manusc.

\section{Funding}

No funding was received.

\section{Availability of data and materials}

All data generated or analysed during this study are included in this published article [and its supplementary information files].

\section{Authors' contributions}

TLR, DRPM, TMB, TKGS, VMM, RAA, JCLRP, ALX, LMB, and MVS participated in study concept and design, data acquisition, data analysis and interpretation and critical revision of the manuscript for important intellectual content. VCOC, and MSS carried out the extraction of essential oil and participated in drafting the manuscript. TLR performed the histopathological analysis. All authors read and approved the final manuscript.

\section{Competing interests}

The authors declare that they have no competing interests.

\section{Consent for publication}

Not applicable.

\section{Ethics approval}

All experimental procedures were previously approved by the Animal Studies Committee from the Federal University of Paraíba (CEUA-UFPB, no. 0510/11).

\section{Publisher's Note}

Springer Nature remains neutral with regard to jurisdictional claims in published maps and institutional affiliations.

\section{Received: 19 January 2017 Accepted: 8 May 2017}

Published online: 03 July 2017

\section{References}

1. Singh S. R. cancer Stem cells: recent developments and future prospects. Cancer Lett. 2013;338(1):1-2.

2. Jemal A, Bray F, Center MM, Ferlay J, Ward E, Forman D. Global cancer statistics. CA Cancer J Clin. 2013;61:69-90.

3. Karolak-Wojciechowska J, Mrozek A, Amiel P, Brouant P, Barbe J, Acta Kasala ER, Bodduluru LN, Madana RM, Athira KV, Gogoi R, Barua CC. Chemopreventive and therapeutic potential of chrysin in cancer: mechanistic perspectives. Toxicol Lett. 2015;233:214-25.

4. Cragg GM, Newman DJ. Natural products: a continuing source of novel drug leads. Biochim Biophys Acta. 1830;2013:3670-95.

5. Moura APG, Beltrão DM, Pita JCLR, Xavier AL, Brito MT, Sousa TKGD, et al. Essential oil from fruit of Xylopia langsdorffiana: antitumour activity and toxicity. Pharm Biol. 2016;54:3093-102

6. Meireles DRP, Fernandes HMB, Rolim TL, Batista TM, Mangueira VM, Sousa TKG, Pita JCLR, Xavier AL, Beltrão DM, Tavares JF, Silva MS, Medeiros KKP, Sobral MV. Toxicity and antitumor efficacy of Croton Polyandrus oil against Ehrlich ascites carcinoma cells. Rev bras farmacogn. 2016;26:751-8.
7. Xavier AL, JCLR P, Brito MT, DRP M, Tavares JF, Maia SMS, JGS AEHA, MFFM D, Silva TG, HLF P, Sobral MV. Chemical composition, antitumor activity, and toxicity of essential oil from the leaves of Lippia Microphylla. Zeitschrift fur Naturforschung. J Biosci. 2015;70:129-37.

8. Bhalla Y, Gupta VK, Jaitak V. Anticancer activity of essential oils: a review. J Sci Food Agric. 2013;93:3643-53.

9. Souza CV, Lorenzi H. Botânica Sistemática. 2nd ed. São Paulo. Nova Odessa: Instituto Plantarum; 2008.

10. Souza LKH, De Oliveira CMA, Ferri PH, et al. Antimicrobial activity of Hyptis Ovalifolia towards dermatophytes. Mem Inst Oswaldo Cruz. 2003;98:963-5. 2003

11. De Oliveira CMA, Silva MDRR, Kato L, Da Silva CC, Ferreira HD, Souza LKH. Chemical composition and antifungal activity of the essential oil of Hyptis Ovalifolia Benth. (Lamiaceae). J Braz Chem Soc. 2004;15:756-9.

12. Barbosa PPP, Ramos CP. Studies on the antiulcerogenic activity of the essential oil of Hyptis mutabilis Briq. In rats. Phytother Res. 1992:6:114-5.

13. Bueno AX, Moreira ATS, Silva FT, Estevam CS, Marchioro M. Effects of the aqueous extract from Hyptis pectinata leaves on rodent central nervous system. Rev bras farmacogn. 2006;16:317-23.

14. Bispo MD, Mourão RHV, Franzotti EM. Antinociceptive and antiedematogenic effects of the aqueous extract of Hyptis pectinata leaves in experimental animals. J Ethnopharmacol. 2001;76:81-6.

15. Falcão HS, Lima IO, Santos VL, Dantas HF, Diniz MFFM, Barbosa-Filho JM, Batista LM. Review of the plants with anti-inflammatory activity studied in Brazil. Rev bras farmacogn. 2005;15:381-91.

16. Ximenes RM, Melo AM, Magalhães LPM, Souza IA, Albuquerque JFC. Antitumor Activity of Leaves from Hyptis mutabilis (A. Rich.) Briq. (Lamiaceae) in Mice Bearing Tumor. Dataset Papers in Pharmacology. 2013:2013:1-3.

17. Silva VA, Andrade LHC. O significado cultural das espécies botânicas entre indígenas de Pernambuco: o caso Xucuru. Biotemas. 2004;17:79-94.

18. Fernandes A. Fitogeografia brasileira. Multgraf editora: Fortaleza; 1998.

19. Matos FJA. Plantas da Medicina Popular do Nordeste: propriedades atribuídas e confirmadas. 1999. Editora da UFC, Fortaleza, p. 80

20. Adams RP. Identification of essential oil components by gas chromatography/ quadrupole mass spectroscopy. Carol Stream: Allured Publ. Corp; 2001. p. 456

21. Van Den Dool H, Kratz PD. A generalization of the retention index system including linear temperature programmed gas - liquid partition chromatography. J Chromatogr A. 1963;11:463-71.

22. Kang C, Munawir A, Cha M, Sohn E-T, Lee H, Kim JS, Yoon WD, Lim D, Kim E. Cytotoxicity and hemolytic activity of jellyfish Nemopilema nomurai (Scyphozoa: Rhizostomeae) venom. Comp Biochem Physiol. 2009;150:85-90.

23. Ribeiro LR. In: Ribeiro L, Salvadori D, Marques E, editors. Teste do micronúcleo em medula óssea de roedores in vivo. Mutagênese Ambiental. Canoas: Editora da ULBRA; 2003. p. 173-6.

24. Organisation for Economic Co-operation and Development (OECD). Acute oral toxicity. Guideline for testing of chemicals, vol. 423; 2001. p. 1-14

25. OECD. Mammalian erythrocyte micronucleus test. OECD guideline for testing of chemicals; 1997. p. 474

26. Dolai N, Karmakar I, Kumar RBS, Kar B, Bala A, Haldar PK. Evaluation of antitumor activity and in vivo antioxidant status of Anthocephalus cadamba on Ehrlich ascites carcinoma treated mice. J Ethnopharmacol. 2012:142:865-70.

27. Maroni LC, Silveira ACO, Leite EA, Melo MM, Ribeiro AFC, Cassali GD, Souza CM, Souza-Fagundes EM, Caldas IR, Araújo MSS, Martins-Filho OA, Oliveira MC, Teixeira-Carvalho A. Antitumor effectiveness and toxicity of cisplatinloaded long-circulating and $\mathrm{pH}$-sensitive liposomes against Ehrlich ascitic tumor. Exp Biol Med. 2012;237:973-84.

28. Pita JCLR, Xavier AL, Sousa TKGS, Vm M, Tavares JF, RJDO J, MVS C-B, et al. In vitro and in vivo antitumor effect of trachylobane-360, a diterpene from Xylopia langsdorffiana. Molecules. 2012;17:9573-89.

29. Falcão DQ Menezes FS. Ver. Bras. Farm. 2003:84:69-74

30. Zbidah M, Lupescu A, Herrmann T, Yang W, Foller M, Jilani K, Lang F. Effect of honokiol on erythrocytes. Toxicol in Vitro. 2013:27:1737-45.

31. Santos Júnior HM, et al. Evaluation of native and exotic Brazilian plants for anticancer activity. J Nat Prod. 2010;64:231-8.

32. Mendanha SA, Moura SS, Anjos JLV, Valadares MC, Alonso A. Toxicity of terpenes on fibroblast cells compared to their hemolytic potential and increase in erythrocyte membrane fluidity. Toxicol in Vitro. 2013;27:323-9.

33. Bakkali $F$, Averbeck S, Averbeck D, Idaomar M, et al. Biological effects of essential oils - a review. Food Chem Toxicol. 2008;46:446-75. 
34. Algariri K, Atangwho IJ, Meng KY, Asmawi MZ, Sadikun A, Murugaiyah V. Antihyperglycaemic and toxicological evaluations of extract and fractions of Gynura Procumbens leaves. Trop Life Sci Res. 2014;1:75-93.

35. Amelo W, Nagpal P, Makonnen E. Antiplasmodial activity of solvent fractions of methanolic root extract of Dodonaea Angustifolia in plasmodium berghei infected mice. BMC Complement Altern Med. 2014;1:1.

36. Nai GA, De Oliveira MC, De Oliveira TG, Pereira LFF, Soares NDSL, Silva PG. Avaliação da genotoxicidade induzida pela administração repetida de anestésicos locais: um estudo experimental em ratos. Rev Bras Anestesiol. 2015;65:21-6.

37. Belcavello L, Cunha MRH, Andrade MA, Batitucci MCP. Citotoxicidade e danos ao DNA induzidos pelo extrato de Zornia diphylla, uma planta medicinal. Natureza on line. 2012;10:140-5.

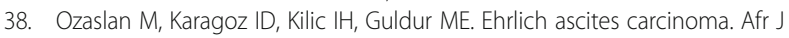
Biotechnol. 2011;10:2375-8.

39. Oliveira MLL, Melo AC. Hipertensão Portal não Cirrótica Associada à Oxaliplatina em Câncer Colorretal. Rev bras cancerol. 2011:57:57-61.

40. Carvalho AA, Andrade LN, De Sousa ÉBV, De Sousa DP. Antitumor Phenylpropanoids Found in Essential Oils. BioMed Res Int. 2015;2015:1-21.

41. Sobral MV, Xavier AL, Lima TC, De Sousa DP. Antitumor activity of Monoterpenes found in essential oils. Scientific World J. 2014;2014:1-35.

42. Chow HHS, Salazar D, Hakim IA. Pharmacokinetics of Perillic acid in humans after a single dose Administration of a Citrus Preparation Rich in dlimonene content cancer epidemiology. Cancer Epidemiol Biomarkers. 2002; 11:1472-6.

43. Loizzo MR, Tundis R, Menichini F, Saab AM, Statti GA. Antiproliferative effects of essential oils and their major constituents in human renal adenocarcinoma and amelanotic melanoma cells. Cell Prolif. 2008;41: 1002-12.

44. Hanahan D, Weinberg RA. Hallmarks of cancer: the next generation. Cell. 2011;144:646-74.

45. Kornberg RD, Lorch Y. Twenty-five years of the nucleosome fundamental particle of the eukaryotic chromosome. Cell. 1999;98:285-94.

46. Dickson MA, Schwartz GK. Development of cell cycle inhibitors for cancer therapy. Curr Opin Oncol. 2009;16:36-43.

47. Xiao XY, Hao M, Yang XY, Ba Q, Li M, Ni SJ, Wang LS, Du X. Licochalcone a inhibits growth of gastric cancer cells by arresting cell cycle progression and inducing apoptosis. Cancer Lett. 2011;302:69-75.

48. Muller HR, Prado KB. Epigenetics: a new genetic field. Rubs. 2008;1:61-9.

49. Darzynkiewicz' S, Del Bino BG, Gorczyca W, Hotz MA, Lassota P, Traganos F. Features of apoptotic cells measured by flow Cytometry. Cytometry. 1992; 13:795-808.

50. Franciscato C, STA L, Santurio JM, Wolkmer P, Maciel RM, de Paula MT, Garmatz BC, Costa MM. Pesq agropec bras. 2006;41:1573-7.

51. Miazzo R, Peralta MF, Magnoli C, Salvano M, Ferrero S, Chiacchiera SM, Carvalho ECQ, Rosa CAR, Dalcero A. Efficacy of sodium bentonite as a detoxifier of broiler feed contaminated with aflatoxin and fumonisin. Poult Sci. 2005:84:1-8.

52. Kodama T, Sendo F, Kobayashi H. Leukemoid reaction in BALB/C mice bearing transplanted tumors. Cancer Res. 1974;34:176-80.

53. Okawa Y, Murata Y, Kobayashi M, Suzuki M, Suzuki S. Augmentation of host resistance to Candida albicans infection in ascites tumor-bearing mice Microbiol Immunol. 1992;36:517-21.

54. Sato DYO, Wal R, De Oliveira CC, Cattaneo RII, Malvezzi M, Gabardo J, Buchi DF. Histopathological and immunophenotyping studies on normal and sarcoma 180-bearing mice treated with a complex homeopathic medication. Homeopathy. 2005;94:26-32.

55. Lins KO, Bezerra DP, Alves AP, Alencar NM, Lima MW, Torres VM, Farias WR, Pessoa C, De Moraes MO, Costa-Lotufo LV. Antitumor properties of a sulfated polysaccharide from the red seaweed Champia Feldmannii (Diaz-Pifferer). J Appl Toxicol. 2009:29:20-6.

56. Torti VR, Cobb AJ, Everitt JL, Marshall MW, Boorman GA, Buterworth BE. Nephrotoxicity and hepatotoxicity induced by inhaled bromodichloromethane in wild-type and p53-heterozygous mice. Toxicol Sci. 2001:64:269

\section{Submit your next manuscript to BioMed Central and we will help you at every step:}

- We accept pre-submission inquiries

- Our selector tool helps you to find the most relevant journal

- We provide round the clock customer support

- Convenient online submission

- Thorough peer review

- Inclusion in PubMed and all major indexing services

- Maximum visibility for your research

Submit your manuscript at www.biomedcentral.com/submit 